\title{
The chromosomal effects of GSM-like electromagnetic radiation exposure on human fetal cells
}

\author{
Nur Uslu ${ }^{1}$, Osman Demirhan ${ }^{1 *}$, Mustafa Emre ${ }^{2}$ and Gülşah Seydaoğlu ${ }^{3}$ \\ ${ }^{1}$ Department of Medical Biology and Genetics, Faculty of Medicine, Çukurova University, 01330 Balcali, Adana, Turkey \\ ${ }^{2}$ Department of Biophysics, Faculty of Medicine, Çukurova University, 01330 Balcali, Adana, Turkey \\ ${ }^{3}$ Department of Biostatistics, Faculty of Medicine, Çukurova University, 01330 Balcali, Adana, Turkey
}

\begin{abstract}
Context: Nowadays, virtually everybody is exposed to radiofrequency radiation (RFR) from mobile phone base station antennas or other sources. Despite many research efforts and public debate there is still great concern about the possible adverse effects of RFR on human health. The present study was designed as an attempt to correlate the effect of non-thermal radiation.
\end{abstract}

Objective: The aim of this study was to evaluate the possible effects of in vitro 900 and $1800 \mathrm{MHz}$ GSM-like (radiation from cell phones) exposure on chromosomes of human fetal cells (FCs).

Materials and methods: We examined the induction of non-thermal effect following $3 \mathrm{~h}, 6 \mathrm{~h}$ and $12 \mathrm{~h}$ exposure to 900 and $1800 \mathrm{MHz}$ radiofrequency radiation (RFEMR) in FCs and in control medium, which did not exposure of RF-EMR.

Results: The results indicated that a significant difference of chromosomal aberrations (CAs) between medium grown cells the exposure of FCs to RF-EMR at 900 and $1800 \mathrm{MHz}$ and unexposed cells, determined by the $\chi 2$ test $(P<0.001)$. We found CAs in 25.9\% of cells exposed to RF radiation [such as fragility, gap, singlestrand breaks (SSB) and double-strand breaks (DSB)], and non-thermal RF-EMF caused delays in chromosome condensation, and a significant rise in CAs with increasing exposure time.

Conclusion: Results of this study confirm that the GSM-like RF-EMR leads to significant direct genotoxic effects on human FCs in vitro culture, and RF-EMR had negative effects on human chromosomes, moreover these effects aggravated with exposure time. We concluded that mobile phone risks to human chromosomes and human health. However, we confirm that RF-EMR affects negatively the condensation of chromosomes. Our hope is that the knowledge of mobile phones safety can not only help guide the future design of these instruments, but also affect the selection of procedures in order to ensure safe, efficacious, and efficient system operation.

\section{Introduction}

The human population is chronically exposed to natural and man-made sources of ionizing and non-ionizing radiations, the latter being, for instance, electric and magnetic fields. In the general population there is growing concern of possible adverse health effects due to increasing exposure to mobile phone, together with exposure to other sources of non-ionizing radiation. The possible genetic effects of mobile phone radiation constitute one of the major points of concern. In 1995 the EPA published the results of a conference it sponsored to assess the current state of knowledge of RF biological effects and to address future research needs in this area [1]. In 1996, the World Health Organization established a program designed to review the scientific literature concerning biological effects of electromagnetic fields, identify gaps in knowledge about such effects, recommend research needs, and work towards international resolution of health concerns over the use of RF technology [2]. The possible effects of RF exposure on the genetic material of cells are considered very important since damage to the DNA of somatic cells can be linked to cancer development or cell death whereas damage to germ cells can lead to genetic damage in next and subsequent generations. Past research has resulted in a very large number of scientific publications on this topic. RFR effects on the frequencies of CAs and other cytogenetic damage have been thoroughly studied both in vivo and in vitro. The results are mixed as several studies do report a significant increase in genetic damage after diverse exposures in a range of systems while often very similar studies show negative results. However, many studies were not sufficiently characterized, are therefore difficult to replicate and cannot be compared to others. Furthermore, the possibility of combined effects of RFR with environmental carcinogens/mutagens merits further attention. Despite many research efforts and public debate there is still great concern about the possible adverse effects of RFR on human health. Therefore, we tried to understand the non-thermal effect of RF on chromosomes of FCs.

\section{Materials and methods}

In this study, for examining the non-thermal effect of RF on chromosomes of FCs (amniocytes), amniotic fluids were obtained from pregnant woman who have applied to the Department of Gynecology

*Correspondence to: Osman Demirhan, Department of Medical Biology and Genetics, Faculty of Medicine, Çukurova University, 01330 Balcali, Adana, Turkey, Tel: 90-322-3387140, Fax: 90-322-3386572, E-mail: osdemir@cu.edu.tr

Key words: radiofrequency electromagnetic fields, genotoxicity, human fetal cells, chromosome aberrations

Received: October 01, 2019; Accepted: October 17, 2019; Published: October 21,2019 
and Obstetrics, Balcali Hospital of Çukurova University with an aim of routine karyotype analysis. In this context, amniotic fluids $(5 \mathrm{~mL})$ were obtained from 25 pregnant women. In a coordinated manner, obtained amniotic fluids were transferred to Cytogenetic Laboratory in the Department of Medical Biology and Genetics. Standard amniocyte culturing method was performed with all samples. FCs were irradiated by using a RF signal generator obtained from Set Electronic, Co. Ltd. (model GHZ2011X, Sakarya, Turkey) (Figure 1a) [3]. Irradiation was performed at radio frequencies of 900 and $1800 \mathrm{MHz}$, and by using continuous-waves (wave impedance $=\mathrm{E} / \mathrm{H}=377,5 \Omega$ ). The signals were amplitude-modulated by rectangular pulses with a pulse repetition frequency (prf) of $217 \mathrm{~Hz}$, pulse duration $0.576 \mathrm{~ms}$ and a duty cycle of $1: 8=0.125 \mathrm{~ms}$, corresponding to the dominant modulation component of the GSM. FCs were cultured and exposed to RF-EMF, and were continuously exposed for 12 day to culture and then exposed for every day 3, 6 and $12 \mathrm{~h}$ to 900 and $1800 \mathrm{MHz}$ (GSM, Global System for Mobile Communications signal) (SAR1.3 W/kg), respectively (Table 1$)$. The electric field strength within the exposure area was set at $30 \mathrm{~dB}$ and 24,5 $\pm 0,5 \mathrm{~V} / \mathrm{m}$ to achieve a $1,0 \mathrm{~W} / \mathrm{kg}$ whole body average specific absorption rate (SAR).This simulates the actual exposure levels from the available GSM mobile phones to the direction of the human tissues. It is worth noting that the value of $25 \mathrm{~V} / \mathrm{m}$ is equivalent to SAR value of $1,0 \mathrm{~W} /$ $\mathrm{kg}$ for $900 \mathrm{MHz}$ [4]. The average power density (ExH) was about 1,59 $\mathrm{W} / \mathrm{m}^{2}$ as determined with a calibrated detector and radio frequency meter (Figure 1c). The antenna was placed at distance of $2 \mathrm{~cm}$ from the flasks (Figure 1b).The exposure cage was a plastic cage with a length of $38.5 \mathrm{~cm}$, a width of $26.0 \mathrm{~cm}$ and a height of $15.5 \mathrm{~cm}$. The distance between the cage and the RF GSM signal generator was maintained at $25 \mathrm{~cm}$. The antenna was placed at distance of $2 \mathrm{~cm}$ from the petri dishes (Figure 1b). Control group were cultured in the medium without RF. Cells were incubated under conditions of $37^{\circ} \mathrm{C}, 5 \% \mathrm{CO} 2$ and proper humidity. At the sixth day of culturing procedure, culture flasks were controlled under invert microscope, and growth conditions of each flask were noted. Then, for medium changing procedure, old mediums were spilled into a glass and then fresh mediums were added to all flasks in the laminar flow device and under sterile conditions. At the eleventh day of culture procedure, flasks were controlled again with observation of full growth of cells, ready for harvesting process. In terms of cell growth levels, no differentiations were observed between groups, for either days of control (sixth and eleventh days). Then all flasks were taken in harvesting procedure, using standard harvesting method, and finally slides were prepared. After three days of incubation of slides (in a $37^{\circ} \mathrm{C}$ incubator), chromosomes were stained, using standard GTG banding technique and analyzed under computer enhanced light microscope with cytovision program. For the CAs analysis, metaphase cells were evaluated for each subject. The collected data were registered on master tables and later transferred to a computer file. For statistical analysis, the SPSS11.0 software program was used. The $\chi 2$ test was applied to determine the significance of the difference of CAs frequencies between the study and the control group.

\section{Analysis}

Statistical analyses were performed by using the SPSS 19.0 program. The correlation and relationship between the end-stage of the treatment and the duration of the RF-EMR application was evaluated by using the $\chi 2$ test statistic. Probit analysis was used to assess the overall duration of RF-EMR application. For all of the tests, a p value below 0.05 was considered as indicative of statistical significance.

\section{Results}

Table 2 displayed the results of the structural CAs of FCs between 900 and $1800 \mathrm{MHz}$ RF-exposure groups. The microscopic images of each particular CA are listed in figure 1 in RF-exposed FCs. FCs were cultured and exposed to 900 and $1800 \mathrm{MHz}$ electromagnetic non-thermal radiation and were continuously exposed for 12 day to culture and then exposed for every day 3,6 and $12 \mathrm{~h}$ for each RF (total six groups) (Table 2). A total of 1200 cells were analysed. revealed predominantly numerical aberrations. Metaphase chromosomes in 200 cells for each group (a total of 1200 cells) were analysed. A total of 600 cells were examined for the analysis of cells 129 to $900 \mathrm{MHz}$ and to $1800 \mathrm{MHz}$ in 182 of the 600 cells examined chromosomal damage was detected. In cultured to create 900 and $1800 \mathrm{MHz}$ RF-EMA, a total of $311(25.9 \%)$ cells revealed CAs in 1200 cells analysed. In the control group, the CAs were found in 16 (2.7\%) of 600 analysed cells. There was a significant difference in the frequencies of CAs between the cutlers exposed to RF-EMF and control determined by the $\chi 2$ test $(P<0.001)$. Additionally, after exposure to the 900 and 1800 of RF-EMF, a dose effect relationship is also found between dose of RF-EMF and chromosome damages $(\mathrm{P}<0.001)$. It was found that the more chromosome damages were increased in 1800 dose of RF-EMF $(\mathrm{P}<0.01)$ (Table 3). Structural changes were observed in $25.9 \%$ of all cells and usually consisted of fragile sites (FS), gaps, chromatid breaks (inversions, deletions and dicentric chromosome) in various chromosomes (Figure 2). Numerical aberrations were not observed. Structural changes were observed usually consisted of FS and gaps in various chromosomes (Table 2). These findings indicate that the duration of mobile phone use increases, increasing the number of structural CAs. No thermal effect of RFEMF in cells leads to corruption delays in chromosome condensation, fragility and breaks. In generally, $96.6 \%$ of CAs revealed predominantly fragilities and gaps. The percentage of cells with total chromatid breaks, inversions, deletions and dicentric structural CAs were $3.1 \%$ and $6.5 \%$ in $900 \mathrm{MHz}$ and $1800 \mathrm{MHz}$, respectively. In cells exposed to the primary focus of this in vitro pilot study was to evaluate if exposure to continuous or pulsed $2.3 \mathrm{GHz}$ electromagnetic radiation of the type used in different mobile phone and wireless network technology

Table 1. The values measured by electrosmog meter

\begin{tabular}{|c|c|c|}
\hline & $900 \mathrm{MHz}$ [2 Watt] & $1800 \mathrm{MHz}$ [1 Watt] \\
\hline Electric Field Intensity & $11,6 \mathrm{~V} / \mathrm{m}$ & $13,3 \mathrm{~V} / \mathrm{m}$ \\
\hline Magnetic Field Intensity & $29,2 \mathrm{~A} / \mathrm{m}$ & $36,7 \mathrm{~A} / \mathrm{m}$ \\
\hline Power Density & $268,4 \mathrm{~mW} / \mathrm{m}^{2}$ & $520 \mathrm{~mW} / \mathrm{m}^{2}$ \\
\hline
\end{tabular}
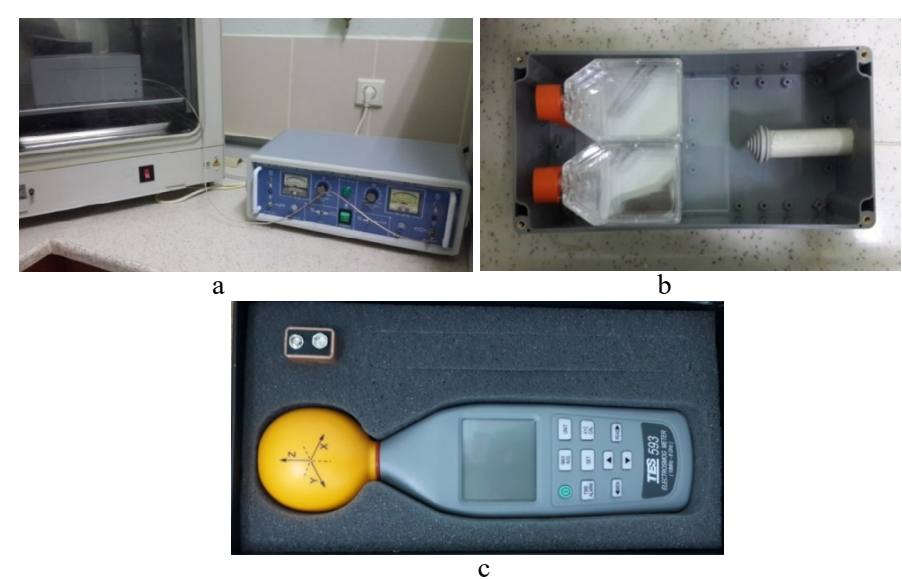

c

Figure 1. During the study, a GSM signal generator was used to create RF-EMR. GSM-like radiofrequency exposure system used to create 900 and $1800 \mathrm{MHz}$ RF. 
Table 2. Chromosome aberrations in fetal cells which were cultured to create 900 and $1800 \mathrm{MHz}$ RF-EMA

\begin{tabular}{|c|c|c|c|c|c|}
\hline \multicolumn{3}{|c|}{ Exposure times in 900 MHz RF-EMA } & \multicolumn{3}{|c|}{ Exposure times in $1800 \mathrm{MHz}$ RF-EMA } \\
\hline 3 hours & 6 hours & 12 hours & 3 hours & 6 hours & 12 hours \\
\hline $\begin{array}{l}\operatorname{gap}(4 \mathrm{q} 31)[1] \\
\operatorname{gap}(3 \mathrm{p} 25)[15] \\
\operatorname{gap}(5 \mathrm{q} 31)[1] \\
\operatorname{gap}(1 \mathrm{q} 24)[1] \\
\text { fra(5q23.2)[1] } \\
\text { fra(6q21)[1] } \\
\text { fra(2q33)[1] } \\
\text { fra(7q32)[1] } \\
\text { fra(1q32)[6] }\end{array}$ & $\begin{array}{l}\text { chtb(1q21)[1] } \\
\operatorname{fra}(3 \mathrm{p} 25)[15] \\
\operatorname{gap}(1 \mathrm{q} 32)[1] \\
\operatorname{fra}(3 \mathrm{p} 32)[1] \\
\operatorname{gap}(6 \mathrm{p} 21)[3] \\
\operatorname{fra}(\mathrm{Xp} 22)[2] \\
\operatorname{fra}(\mathrm{Xq27})[2] \\
\operatorname{fra}(9 \mathrm{q} 22)[1] \\
\operatorname{gap}(5 \mathrm{q} 32)[5] \\
\operatorname{gap}(10 \mathrm{q} 22)[3]\end{array}$ & $\begin{array}{l}\operatorname{inv}(9 \mathrm{p} 11 ; \mathrm{q} 12)[1], \\
\text { chtb(2p23)[1] } \\
\text { chtb(6q2-qter)[1], } \\
\text { fra(Xq25)[4], } \\
\text { fra(Xq26)[5], } \\
\text { fra(2q33)[2], } \\
\text { fra(13q13)[1] } \\
\text { gap(6q21)[2], } \\
\text { gap(10q22)[3] } \\
\text { gap(5q32)[3] } \\
\text { gap(5q32)[10] } \\
\text { fra(4q31)[1], } \\
\text { gap(1p22)[1] } \\
\text { gap(3p25)[1], } \\
\text { gap(4q33)[2] } \\
\text { gap(1q32)[5], } \\
\text { gap(14q23)[1] } \\
\text { gap(4q31)[1], } \\
\text { gap(3p25)[15] } \\
\text { gap(5q31)[4], } \\
\text { gap(1q24)[1] } \\
\text { gap(14q24)[1], } \\
\text { gap(15q15)[1] }\end{array}$ & $\begin{array}{l}\operatorname{del}(10 \mathrm{q} 26)[2] \\
\operatorname{fra}(6 \mathrm{q} 21)[4], \\
\text { fra(7q32)[4] } \\
\text { fra(6q24)[2], } \\
\text { fra(1p36)[4] } \\
\text { fra(6p23)[2], } \\
\text { fra(5q32)[2] } \\
\text { fra(3p25)[2], } \\
\text { fra(8q21)[1] } \\
\text { fra(Xq28)[1], } \\
\text { fra(Xq22)[1] } \\
\operatorname{gap}(X q 23)[1] \\
\operatorname{gap}(1 \mathrm{q} 21)[1] \\
\operatorname{gap}(3 \mathrm{q} 21)[1] \\
\operatorname{gap}(1 \mathrm{q} 32)[1], \\
\text { qh+[2] }\end{array}$ & 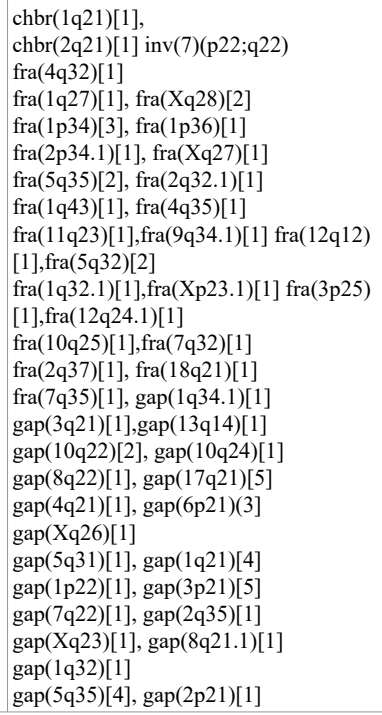 & $\begin{array}{l}\text { chtbr(3q13)[1] } \\
\text { chtbr(2q24)[1] } \\
\text { chtbr(6q12)[1] } \\
\text { chtbr(2q32)[1] } \\
\text { chtbr(12q13)[1], } \\
\operatorname{dic}(3 \mathrm{q} 25)[1] \\
\text { 9qh+[1], } \\
\text { gap(1q32)[10],gap(3p21)[11] gap(1q21) } \\
\text { [1],gap(1q42)[1] gap(1p22)[1],gap(1p36) } \\
\text { [2] gap(18q21)[1],gap(2p23)[1] gap(14q24) } \\
\text { [3],gap(4q31)[2] gap(9q21)[1],gap(5q32) } \\
\text { [4], gap(7q22)[2],gap(14q24)[1] gap(2q23) } \\
\text { [1],gap(10q22)[5] gap(2q31)[3],gap(17q21) } \\
\text { [2] gap(1q23)[2] } \\
\operatorname{gap}(4 \mathrm{q} 27)[1], \operatorname{gap}(3 \mathrm{q} 21)[1] \text { fra(1q21)[2], } \\
\text { fra(1q41)[1 } \\
\text { fra(3p25)[1], fra(2p23)[1] } \\
\text { fra(2p21)[2], fra(12q14)[2] } \\
\text { fra(1p36)[1], } \\
\text { fra(5q23.2)[1 } \\
\text { fra(6q21)[1], } \\
\text { fra(2q33)[1] } \\
\text { fra(7q32)[1],fra(3q21)[1] fra(Xq27.3)[1] } \\
\text { fra(8q24.1)[1], 1qhsr+[1] }\end{array}$ \\
\hline
\end{tabular}

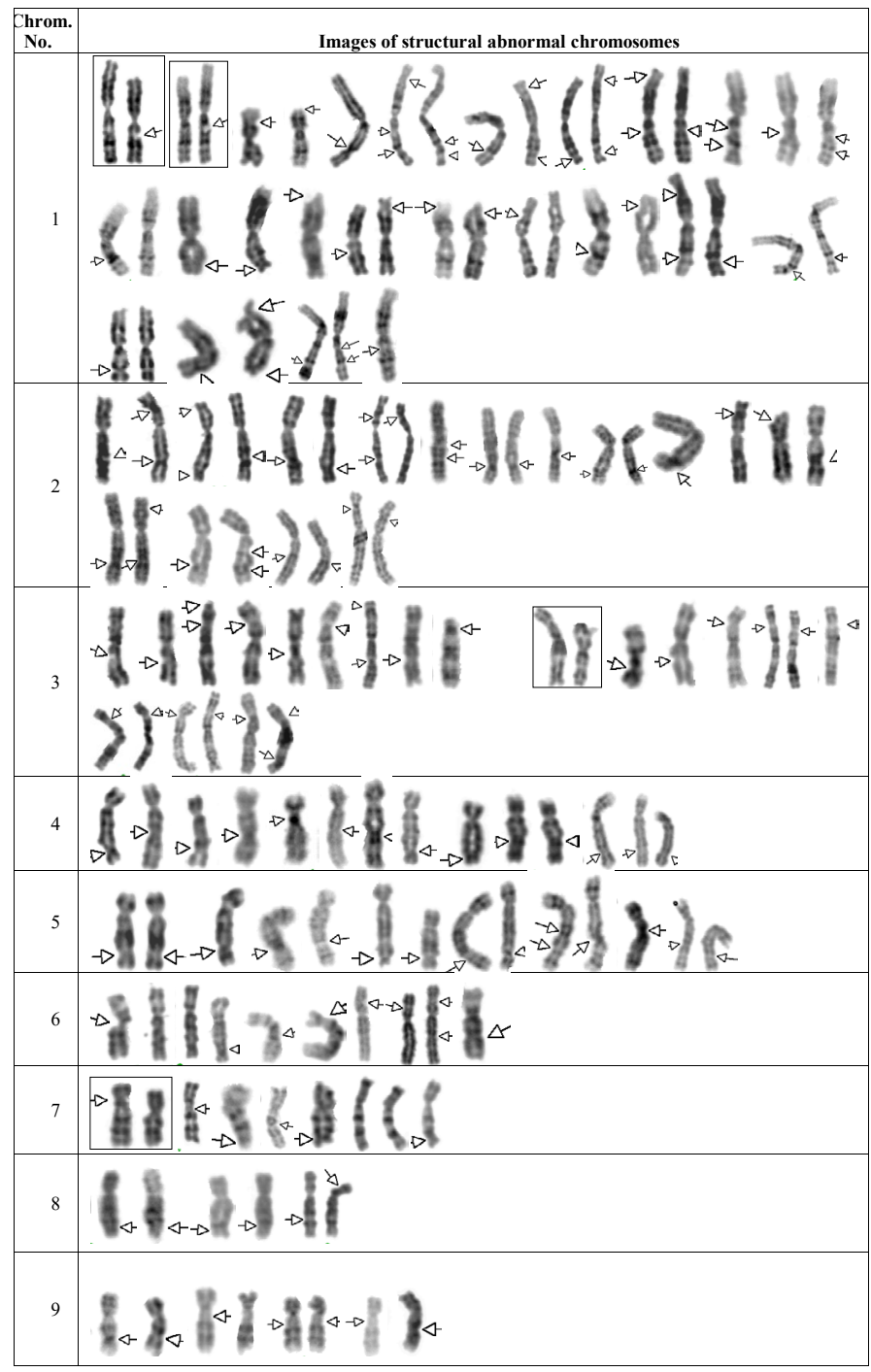

Figure 2. Some partial metaphase figures showing some chromosomal abnormalities of fetal cells, cultured to create 900 and 1800 MHz RF-EMA.
Table 3. The statistical evaluation of chromosome aberrations observed in the amniotic cells exposed to RF-EMF

\begin{tabular}{|c|c|c|c|c|c|}
\hline \multirow{3}{*}{$\begin{array}{l}900 \\
\text { MHz }\end{array}$} & & \multicolumn{4}{|c|}{ Exposure times } \\
\hline & & 3 hours & 6 hours & 12 hours & p-value \\
\hline & $\begin{array}{l}\text { Cells with chromosomal } \\
\text { abnormalities/ Percent }\end{array}$ & $28 / 14.0$ & $34 / 17.0$ & $67 / 33.5$ & \multirow{2}{*}{0.0001} \\
\hline \multirow{2}{*}{$\begin{array}{l}1800 \\
\mathrm{MHz}\end{array}$} & Normal cells & 172 & 166 & 133 & \\
\hline & $\begin{array}{l}\text { Cells with chromosomal } \\
\text { abnormalities/ Percent }\end{array}$ & $31 / 15.5$ & $70 / 35.0$ & $81 / 40.5$ & \multirow[t]{2}{*}{0.0001} \\
\hline \multirow{2}{*}{$p$-value } & \multirow{2}{*}{ Normal cells } & 169 & 130 & 119 & \\
\hline & & 0.672 & 0.0001 & 0.147 & \\
\hline
\end{tabular}

would induce chromosomal damage in human lymphocytes. the most common chromosome damages were observed as common findings on chromosome $3,5,1, \mathrm{X}, 6,10,4$ and 2 , respectively. In the exposed cells treated with $1800 \mathrm{MHz}$, the most damages were seen in chromosome 1, $3,2,5,6,7,10$, $\mathrm{X}$ and 4, respectively (Table 2).

\section{Discussion}

In the present paper, we evaluate the effects of exposures to mobile phones generated electromagnetic fields. To our knowledge this is the first study on the genetic effects of the non-thermal radiation generated during RF-exposed human FCs. Mobile phones have come into widespread use and play an increasingly more prominent role in daily life. It is generally claimed that RF-EMR fields from cell phones can exert a variety of toxic effects on mammalian cells [5]. Possible effects of RF on DNA or chromosome structure in somatic cells are considered to be very important as these changes could be associated with cell death or, possibly, with the development of cancer. The primary focus of the present study was to evaluate if exposure to continuous $3 \mathrm{~h}, 6 \mathrm{~h}$ and $12 \mathrm{~h}$ to $900 \mathrm{MHz}$ and $1800 \mathrm{MHz}$ electromagnetic non-thermal radiation of the type used in mobile phone would induce chromosomal damage in human FCs. A statistically significant increase was found in the frequency of structural CAs between RF-exposed cells and unexposed cells $(P<0.001)$. Structural changes were observed in nearly $26 \%$ of RFexposed cells and usually consisted of fragilities, gaps, chromatid and chromosome breaks, deletions and inversions in various chromosomes. Among these CAs, the number of fragilities and gaps were higher in the RF-exposed cells $(96.9 \%$ in $900 \mathrm{MHz}$ and $93.5 \%$ in $1800 \mathrm{MHz})$. 
The results obtained in the present study indicate that chromosome condensation is affected by non-ionizing radiation, and RFR-exposed FCs had a higher incidence of FSs. The fragility of the chromosome may be related to abnormalities in replication, resulting in single-strand DNA gaps, which, if not repaired, may lead to chromosome damage such as deletions within the FS, or translocations or other rearrangements involving breakage at a FS. Therefore, it may be considered that the expression of FS could be an indicator of chromosomal instability within the genome of RFR-exposed individuals. At the same time, the RFR increases the potential for chromosome breakage at cancer sites in the genome, and it also may increase the risk for breakage or deletion in RFR-exposed individuals.

Literature search of RF-induced genetic damage in vitro or in vivo in animals learns that there is a lot of controversy because positive as well as negative results were regularly reported [6-11]. So far, a rather great number of cytogenetic investigations were already devoted to RFR radiations, including those from mobile phone frequencies. Most studies are negative suggesting that RFR is not directly mutagenic and that adverse RFR effects are predominantly the result of hyperthermia. Investigations on cytogenetic effects of RFR-exposed human lymphocytes (CAs, sister chromatid exchanges and micronucleus induction) yield contradictory and often intriguing results. Many studies failed to find any indication of an RFR-induced genetic effect, but some did. Among the positive findings, some studies are often cited [12-14]. Some investigations have suggested that RF-fields yet can affect DNA. Ros Lior [15], investigated the effect of cell phones on the frequency of micronucleus in oral mucosal cells obtained from humans, and identified no genotoxicity in association with RF-EMR. Similarly, no DNA damage associated with RF-EMR was observed in murine fibroblasts [16,17] and human blood cells [18]. However, there is too much controversy yet to allow a definite conclusion. Reasons for the existence of controversial data may be that in some of the reports important experimental details which are critical for independent verification were either inadequately or non-described, such as, RFR exposure conditions, dosimetry, specific absorption rate and temperature measurements [19]. Hence, it is not always possible to estimate the exposure conditions adequately and discriminate between thermal or non-thermal exposures which may certainly account for differences in response of cells or organisms. Furthermore, it is clear that variables exist in experimental protocols in terms of the frequency applied, the modulation, investigated genetic endpoints, cell type used, etc. At least some papers tend to attribute the controversial results to these differences.

The possible association between RF exposure due to mobile phone use and cancer has been largely subjected to epidemiological studies. Most of these studies found no association [20,21] while only a few suggested possible links [22]. The possibility that RF-EMR from cell phones might lead to an increase in the incidence of brain cancer, has become an intensively debated topic [23]. Yet, the assumption that genetic effects are exclusively and, in all cases, predictive for cancer is certainly an overstatement. However, it noted that avoiding excessive cell phone usage should be considered as one of the possible precautions against cancer $[24,25]$ since excessive cell phone use rather than the more use of cell phone might be positive factor for cancer incidence. Oncogenes and tumour suppressor genes are clustered around recombination hot spots or fragile sites in the genome, because double-strand break is the common initial step in translocation, deletion and gene amplification [26]. Therefore, it may be considered that the expression of FS could be an indicator of chromosomal instability within the genome of cancers.
The characterization of FS has demonstrated that they are associated with genes that relate to tumorigenesis $[27,28]$. The results obtained in the present study indicate that an RFR-exposed FCs had a higher incidence of fragile sites (FSs). Identification of the basis of instability at FS and the related genes provide an entree for understanding the important aspects of chromosomal instability, which is a prominent feature of RFR-exposed FCs. Among these expressed fragilities and breaks, specifically, the break expression at 1q21 was observed. This region may be hot spots or associated with tumour, and as potential loci for harbouring genes that are important in the development and progression of cancers. Thus, chromosome 1 abnormalities are often seen as a secondary change in a number of tumour types [29], including atypical lipomas and well differentiated liposarcomas [30,31]. In previous studies, the 1q21 region was reported to include and harbour susceptibility genes for lung cancer [32,33]. It was marked that consistent breaks and deletions involving specific oncogenes/ tumour suppressor genes were present in 1 p36 and other regions of chromosome 1 , such as 1p22-q21 [34,35]. The NORE1 gene at 1q32.1 was isolated homologous to the tumor suppressor gene RASSF1A [36]. The FCs and breaks at band q21, q32 and q36 on chromosome 1 were also significantly overexpressed in our patients. All these findings indicate that the chromosome $1 \mathrm{q}$ could play a role in the pathogenesis of cancer.

In the present study, the changes of chromosome 2; fragility at band p23, q24, q21, q32 and q33 were significantly overexpressed. Some genes on chromosomes 2 are known to play a role for tumour development, and may be affected by these alterations, PMS1 (2q34; apoptosis and maintenance of genomic stability) and CDK7 (2p15cen) [34]. Therefore, the chromosome regions $2 \mathrm{p}-\mathrm{q}$ could play a role in the pathogenesis of cancer. We reported to be most frequent the CAs at bands q13, q21 and p25 of chromosome 3. Rearrangements at 3p14.2 occur frequently in most human cancers $[37,38]$. Losses of three distinct regions on chromosome 3 have also been identified at 3p21.3, 3p14 and 3 p25, suggesting the presence of multiple tumour suppressor genes [39]. Some tumour suppressor genes on $5 q 31$ are also important in haematological transformation $[40,41]$. In our study, the FCs and gaps of distinct regions on chromosome 5 have also been identified at $5 \mathrm{q} 31$ and $5 \mathrm{q} 35$. Rearrangements of band $6 \mathrm{p} 21$ have been observed frequently in the same group of previously mentioned mesenchymal tumours, including lipomas, pulmonary chondroid hamartomas, endometrial polyps and uterine leiomyomata $[42,43]$. Just as, we identified fragilities at bands $6 \mathrm{q} 12$ and $6 \mathrm{q} 21$ that were provided significantly overexpressed in the RFR-exposed FCs. In the present study, deletions and FCs of distinct regions on chromosome 10 have also been identified. Especially, the deletion at 10q26 region was remarkable to be seen in the two cells. This deletion shows the double-strand DNA breaks. One of the most frequent genetic alterations in glial tumours is heterozygous loss of chromosome 10 which has been associated with malignant progression $[44,45]$. FGFR2 gene on human chromosome 10q26 is amplified in diffuse-type gastric cancer, while WDR11 gene on human chromosome $10 \mathrm{q} 26$ is disrupted in glial tumours [46].

Among the pericentric inversions, those of chromosome 7 are not frequent in human (4.3\%-6.2\% of all pericentric inversion) [47]. Cytogenetic analyses and molecular loss of heterozygosity studies suggest that chromosome band $7 \mathrm{q} 22$ is a critical region that is associated with $7 \mathrm{q}$ - malignant myeloid disorders $[48,49]$. At the present time the tumour-suppressor gene(s) responsible for $\operatorname{del}(7 \mathrm{q})$ fibroid growth has not been identified despite much effort. Loss of genetic material from $7 \mathrm{q}$ and rearrangements specifically involving band $\mathrm{q} 22$ have 
been found more consistently in UL than in any other solid tumour. Hennig et al. show that the most frequent clonal abnormalities were structural rearrangements involving deletions of $7 \mathrm{q}[\operatorname{del}(7)(\mathrm{q} 21)$ and $\operatorname{del}(7)(q 22: q 32)] ~[50]$. We have also detected a pericentric inversion of chromosome 7 (bands p22-q22) in one cell. This inversion is caused by the double-strand DNA breaks. The fundamental importance of the 12q14-15 region in benign neoplasia is supported by the occurrence of consistent rearrangements in numerous other solid benign tumours including lipoma, pleomorphic adenoma of the salivary gland, pulmonary chondroid hamartoma, endometrial polyps and epithelial breast tumours [51,52]. We have also detected the fragilities and gaps in bands q13 of chromosome 12 in RF-exposed cells. In some instances, in this tumour type, the breakpoint have been found to involve the band 12q13-15 [53,54]. The X chromosome fragilities (q25, q26 and q27) were seen in the RF-exposed cells, and these fragile regions were significantly overexpressed in our study. The X chromosome abnormalities have been reported with lower frequency in leiomyomata. These are including: $\operatorname{del}(\mathrm{X}(\mathrm{p} 11.2), \quad(\mathrm{X} ; 12)(\mathrm{p} 22.3 \mathrm{q} 15), \quad-\mathrm{X}, \quad \operatorname{der}(5) \mathrm{t}(\mathrm{X} ; 5)(\mathrm{p} 11 ; \mathrm{p} 15), \quad \operatorname{del}(\mathrm{X})$ $(\mathrm{q} 12), \operatorname{der}(\mathrm{X}) \mathrm{t}(\mathrm{X} ; 3)(\mathrm{p} 22.3 ; \mathrm{q} 11.2)$ and $\operatorname{inv}(\mathrm{X})(\mathrm{p} 22 \mathrm{q} 13)$ [55,56]. Just as, $\mathrm{X}$ chromosome was found to be involved in carcinogenesis and the malignant progression of different types of tumors, and an increasing number of potentially responsible genes have been identified [57]. In particular, chromosomal gains or deletions have been associated with tumoral progression, the presence of metastases, and worse prognosis in tumors of the breast, ovary, and uterine cervix [58,59]. Although, there are numerous X-linked genes that may be involved in neoplasia, including the MAGE tumor-specific antigen loci, the pseudoautosomal GM-CSFR gene that likely escapes X chromosome inactivation, and the ARAF1, ELK1, and MCF.2 oncogenes [60-62].

\section{Conclusion}

To our knowledge, our work has been the first, demonstrating any chromosomal effects induced by GSM-like RF-EMR. While it is still not very clear whether proper use of RF fields may be harmful to health and the environment. The results obtained in this work demonstrate that exposure to GSM-like RF-EMR effected severely affected human chromosomes, and the presence of chromosome damages response in human FCs due to acute non-thermal exposure to $900 \mathrm{MHz}$ and $1800 \mathrm{MHz}$ RF for GSM. However, the relatively high incidence of CAs suggests that chromosome condensation is affected by non-ionizing radiation. This genetic damage also would certainly be indicative of a potential serious health risk. Deletions, inversion and dicentric chromosomes alone are reliable indicators of mobile phone RFR of fetal chromosomes. We concluded that mobile phone risks to human chromosomes and health. With regard to potential health effects of mobile phones, especially long-term effects, the available data are at present too scarce. From these considerations, our hope is that the knowledge of mobile phones safety can not only help guide the future design of these instruments, but also affect the selection of procedures in order to ensure safe, efficacious, and efficient system operation. This is the road map for an accountable growth of the health system.

\section{References}

1. US. Environmental Protection Agency, Office of Air and Radiation and Office of Research and Development (1993) Summary and Results of the April 26-27, 1993. Radiofrequency Radiation Conference 1: 402-R-95-009.

2. Repacholi MH (1998) Low-Level Exposure to Radiofrequency Electromagnetic Fields: Health Effects and Research Needs. Bioelectromagnetics 19: 1-19. [Crossref]

3. Boga A, Emre M, Sertdemir Y, Akillioglu K, Binokay S et al. (2015) The effect of 900 and $1800 \mathrm{MHz}$ GSM-like radiofrequency irradiation and nicotine sulfate administration on the embryonic development of Xenopus laevis. Ecotoxicol Environ Saf 113: 378390. [Crossref]
4. Gandhi OP, Lazzi G and Furse CM (1996) Electromagnetic absorption in the human head and neck for mobile telephones at 835 and 1900 MHZ. IEEE Trans. Microw. Theory Tech 44: 1884-1897.

5. Aitken RJ, Bennetts LE, Sawyer D, Wiklendt AM, King BV (2005) Impact of radiofrequency electromagnetic radiation on DNA integrity in the male germline. Int $J$ Androl 28: 171-179. [Crossref]

6. Christ A, Kuster N (2005) Differences in RF energy absorption in the heads of adults and children. Bioelectromagnetics 7: S31-S44. [Crossref]

7. Obe VG (2004) Controversial cytogenetic observations in mammalian somatic cells exposed to radiofrequency radiation. Radiat Res 162: 481-496. [Crossref]

8. Verschaeve L (2005) Genetic effects of radiofrequency radiation. Toxicol Appl Pharmacol 207: 336-341. [Crossref]

9. Brusick D, Albertini R, McRee D, Peterson D, Williams G, et al. (1998) Genotoxicity of radiofrequency radiation. Environ Mol Mutagen 32: 1-16.

10. Meltz ML (2003) Radiofrequency exposure and mammalian cell toxicity, genotoxicity, and transformation. Bioelectromangetics 6: S196-S213.

11. J McNamee, PV Bellier (2004) Cytogenetic and carcinogenetic effects of exposure to radiofrequency radiation. Springer-Verlag, Berlin, Heidelberg, New York, USA, pp: 427-469.

12. Maes A, Collier M, Verschaeve L (2000) Cytogenetic investigations on microwaves emitted by a $455.7 \mathrm{MHz}$ car phone. Folia Biol 46: 175-180. [Crossref]

13. Zotti-Martelli L, Peccatori M, Scarpato R, Migliore L (2000) Induction of micronuclei in human lymphocytes exposed in vitro to microwave radiation. Mutat Res 472: 51-58.

14. Tice RR, Hook GG, Donner M, McRee DI, Guy AW (2002) Genotoxicity of radiofrequency signals: I. Investigation of DNA damage and micronuclei induction in cultured human blood cells. Bioelectromagnetics 23: 113-126. [Crossref]

15. Ros-Llior I, Sanchez-Siles M, Camacho-Alonso F, Lopez-Jornet P (2012) Effect of mobile phones on micronucleus frequency in human exfoliated oral mucosal cells. Oral Dis 8: 786-792. [Crossref]

16. Malyapa RS, Ahern EW, Bi C, Straube WL, LaRegina M, et al. (1998) DNA damage in rat brain cells after in vivo exposure to $2450 \mathrm{MHz}$ electromagnetic radiation and various methods of euthanasia. Radiat Res 149: 637-645. [Crossref]

17. Li L, Bisht KS, Lagroye I, Zhang P, Straube WL, et al. (2001) Measurement of DNA damage in mammalian cells exposed in vitro to radiofrequency fields at SARs of $3-5$ W/kg. Radiat Res 156: 328-332. [Crossref]

18. Maes A, Collier M, Van Gorp U, Vandoninck S, Verschaeve L (1997) Cytogenetic effects of 935.2-MHz GSM microwaves alone and in combination with mitomycin C. Mutat Res 393: 151-156. [Crossref]

19. Vijayalaxmi OG (2004) Controversial cytogenetic observations in mammalian somatic cells exposed to radiofrequency radiation. Radiat Res 162: 481-496.

20. Muscat JE, Malkin MG, Thompson S, Shore RE, Stellman SD, et al. (2000) Handheld cellular telephone use and risk of brain cancer. JAMA 284: 3001-3007. [Crossref]

21. Inskip PD, Hatch EE, Stewart PA, Heineman EF, Ziegler RF, et al. (1999) Study design for a case-control investigation of cellular telephones and other risk factors for brain tumours in adults. Radiat Prot Dosim 86: 45-52.

22. Hardell L, Nasman A, Pahlson A, Hallquist A, Hansson Mild K (1999) Use of cellular telephones and the risk for brain tumours: a case-control study. Int J Oncol 15: 113116. [Crossref]

23. Hao D, Yang L, Chen S, Tong J, Tian Y, et al. (2012) Effects of long-term electromagnetic field exposure on spatial learning and memory in rats. Neurol Sci: 1-8.

24. Munshi A (2011) Cellular phones: to talk or not to talk. J Cancer Res Ther 7: 476-477.

25. Ayanda OS, Baba AA, Ayanda OT (2012) Use of mobile phones and cancer risk. Asian Pac J Cancer Prev 13: 403-436.

26. Masuko K, Masaru K (2003) FGFR2 and WDR11 are neighboring oncogene and tumor suppressor gene on human chromosome 10q26. Int J Oncol 22: 1155-1159. [Crossref]

27. Gericke GS (1998) Chromosomal fragility may be indicative of altered higher-order DNA organization as the underlying genetic diathesis in complex neurobehavioral disorders. Med Hypotheses 50: 319-326. [Crossref]

28. Arrieta I, Núñez T, Martínez B, Pérez A, Télez M, et al. (2002) Chromosomal fragility in a behavioral disorder. Behavior Genet 32: 397-412.

29. Milelman F (1988) Calalog of chromosome aberrations in cancer. ( $3^{\text {rd }}$ edn), Alan R Liss, New York, USA, pp: 37-60. 
30. Heim S, Mandahl N, Kristoffersson U, Mitelman F, Rööser B, et al. (1987) Marker ring chromosome--a new cytogenetic abnormality characterizing lipogenic tumors? Cancer Genet Cytogenet 24: 319-326. [Crossref]

31. Ture-Carel C, Dal Cin P, Rao U, Karakousis C, Sandberg AA (1986) Cytogenetic studies of adipose tissue tumors. I. A benign lipoma with reciprocal translocation 1(3;12)(q28;q24). Cancer Genet Cytogenet 23: 283-289.

32. Mikami Y, Hisatsune A, Tashiro T, Isohama Y, Katsuki H (2009) Hypoxia enhances MUC1 expression in a lung adenocarcinoma cell line. Biochem Biophys Res Commun 379: 1060-1065. [Crossref]

33. Kuemmel A, Single K, Bittinger F, Faldum A, Schmidt LH, et al. (2009) TA-MUC1 epitope in non-small cell lung cancer. Lung Cancer 63: 98-105. [Crossref]

34. Thompson FH, Emerson J, Olson S, Weinstein R, Leavitt SA, et al. (1995) Cytogenetics of 158 patients with regional or disseminated melanoma. Subset analysis of neardiploid and simple karyotypes. Cancer Genet Cytogenet 83: 93-104. [Crossref]

35. Smedley D, Sidhar S, Birdsall S, Bennett D, Herlyn M, et al. (2000) Characterization of Chromosome 1 Abnormalities in Malignant Melanomas. Genes Chromosomes Cancer 28: 121-125. [Crossref]

36. Tommasi S, Dammann R, Jin SG, Zhang XF, Avruch J, et al. (2002) RASSF3 and NORE1: identification and cloning of two human homologues of the putative tumor suppressor gene RASSF1. Oncogene 18: 2713-2720. [Crossref]

37. Sozzi G, Tornielli S, Tagliabue E, Sard L, Pezzella F, et al. (1997) Absence of Fhit protein in primary lung tumors and cell lines with FHIT gene abnormalities. Cancer Res 57: 5207-5212. [Crossref]

38. Corbin S, Neilly ME, Espinosa R, Davis EM, McKeithan TW, et al. (2002) Identification of unstable sequences within the common fragile site at 3p14.2: implications for the mechanism of deletions within fragile histidine triad gene/common fragile site at 3p14.2 in tumors. Cancer Res 62: 3477-3484. [Crossreff]

39. Hibi K, Takahashi T, Yamakawa K, Ueda R, Sekido Y, et al. (1992) Three distinct regions involved in 3p deletion in human lung cancer. Oncogene 7: 445-449. [Crossref]

40. Dubourg C, Toutain B, Helias C, Henry C, Lessard M, et al. (2002) Evaluation of $\mathbf{E T F} 1 / \mathrm{eRF} 1$, mapping to $\mathbf{5 q 3 1}$, as a candidate myeloid tumor suppressor gene. Cancer Genetics and Cytogenetics 134: 33-37. [Crossref]

41. Le Beau MM, Espinosa R, Neuman WL, Stock W, Roulston D, et al. (1993) Cytogenetic and molecular delineation of the smallest commonly deleted region of chromosome 5 in malignant myeloid diseases. Proc Natl Acad Sci U S A 90: 54845488. [Crossref]

42. Williams AJ, Powell WL, Collins T, Morton CC (1997) HMGI(Y) expression in human uterine leiomyoma: involvement of another high-mobility group architectural factor in a benign neoplasm. Am J Path 150: 911. [Crossref]

43. Xiao S, Lux M, Reeves R, Hudson TJ, Fletcher JA (1997) HMGI(Y) activation by chromosome $6 \mathrm{p} 21$ rearrangements in multilineage mesenchymal cells from pulmonary hamartoma. Am J Path 150: 901-910. [Crossref]

44. Saxena A, Shriml LM, Dean M, Ali IU (1997) Comparative molecular genetic profiles of anaplastic astrocytomas/glioblastomas multiforme and their subsequent recurrences. Oncogene 18: 1385-1390. [Crossref]

45. Fujisawa H, Kurrer M, Reis RM, Yonekawa Y, Kleihues P, et al. (1999) Acquisition of the glioblastoma phenotype during astrocytoma progression is associated with loss of heterozygosity on 10q25-qter. Am J Pathol 155: 387-394. [Crossref]
46. Chernova OB, Hunyadi A, Malaj E, Pan H, Crooks C, et al. (2001) A novel member of the WD-repeat gene family, WDR11, maps to the 10q26 region and is disrupted by a chromosome translocation in human glioblastoma cells. Oncogene 20: 5378-5392. [Crossref]

47. De Braekeleer M, Dao TN (1991) Cytogenetic studies in male infertility: a review. Hum Reprod 6: 245-250. [Crossref]

48. Stanley WS, Burkett SS, Segel B, Quiery A, George B, et al. (1997) Constitutiona inversion of chromosome 7 and hematological cancers. Cancer Genet Cytogenet 96: 46-49. [Crossref]

49. Preiss BS, Hasle H, Sorensen AG, Heil M, Kerndrup GB (1999) A case of childhood acute myeloid leukemia associated with inversion (7)(p21q31). Cancer Genet Cytogenet 08: 144-148.

50. Ozisik YY, Meloni AM, Surti U, Sandberg AA (1993) Deletion 7q22 in uterine leiomyomata. A cytogenetic review. Cancer Genet Cytogenet 23: 305-313. [Crossref]

51. Bullerdiek J, Bartnitzke S, Weinberg M, Chilla R, Haubrich J, et al. (1987) Rearrangements of chromosome region 12q13-15 in pleomorphic adenomas of the human salivary gland. Cytogenet Cell Genet 45: 187-190. [Crossref]

52. Mandahl N, Orndal C, Heim S, Mitelman F, Willén H, et al. (1993) Aberrations of chromosome segment 12q13-15 characterize a subgroup of hemangiopericytomas. Cancer 71: 3009-3013.

53. Turc-Carel C, Limon J, Dal Cin P, Rao U, Karakousis C, et al. (1986) Cylogenetie studies

54. of adipose tissue tumors: II. Recurrenl reciproeal translocation $\mathrm{t}(12 ; 18)(\mathrm{q} 13 ; \mathrm{p} 11)$ in mixed liposareomas. Caneer Genet Cytogenet 23: 291-300. [Crossref]

55. Ture-Carel C, Dal Cin P, Rao U, Karakousis C, Sandberg AA (1986) Cytogenetie studies of adipose tissue tumors. I. A benign lipoma with reciprocal translocation 1(3;12)(q28;q24). Cancer Genet Cytogenet 23: 283-289. [Crossref]

56. Vanni R, Lecca U, Faa G (1991) Uterine leiomyoma cytogenetics. II. Report of forty cases. Cancer Genet Cytogenet 53: 247-256. [Crossref]

57. Mark J, Havel G, Grepp C, Dahlenfors R, Wedell B (1990) Chromosomal patterns in human benign uterine leiomyomas. Cancer Genet Cytogenet 44: 1-13. [Crossref]

58. Ross MT, Grafham DV, Coffey AJ, Scherer S, McLay K, et al. (2005) The DNA sequence of the human X chromosome. Nature 434: 325-337. [Crossref]

59. Piao Z, Malkhosyan SR (2002) Frequent loss Xq25 on the inactive X chromosome in primary breast carcinomas is associated with tumor grade and axillary lymph node metastasis. Genes Chromosomes Cancer 33: 262-269. [Crossref]

60. Kersemaekers AM, van de Vijver MJ, Kenter GG, Fleuren GJ (1999) Genetic alterations during the progression of squamous cell carcinomas of the uterine cervix. Genes Chromosomes Cancer 26: 346-354. [Crossref]

61. Wang MG, Zakut R, Yi H, Rosenberg S, McBride OW (1994) Localization of the MAGE1 gene encoding a human melanoma antigen to chromosome Xq28. Cytogenet Cell Genet 67: 116-119. [Crossref]

62. Rao VN, Huebner K, Isobe M, ar-Rushdi A, Croce CM, et al. (1989) Elk, tissue-specific ets-related genes on chromosomes X and 14 near translocation breakpoints. Science 244: 66-70, 1989. [Crossref]

Copyright: (C2019 Uslu N. This is an open-access article distributed under the terms of the Creative Commons Attribution License, which permits unrestricted use, distribution, and reproduction in any medium, provided the original author and source are credited. 